\title{
DETERMINANTS OF VAT GAP IN EU
}

\author{
Hana Zídková*
}

\begin{abstract}
:
This paper explains the term "VAT gap", and briefly describes the calculation methods used in existing literature quantifying the VAT gap in various countries of the world. The VAT gap is calculated as the difference between the theoretical VAT liability ascertained from the national accounts and the VAT revenues accrued by the financial authorities. Although VAT gap is not caused by tax evasion only, it could serve as its indicator. Further, it provides a review of scientific papers and various studies that analyse factors influencing the size of the VAT gap, and summarizes the results of these empirical studies. The main purpose of this article is to perform a regression analysis of potential variables explaining the VAT gap in 24 EU Member States in two selected years (2002 and 2006) for which data on the VAT gap was available. Two factors common for both examined years affecting the VAT gap in the surveyed countries were found, being the final consumption of households and non-profit organizations in each state, with a positive impact on the VAT gap, and the share of VAT in GDP, reducing the VAT gap. Other identified variables that would explain the size of the VAT gap were the share of the shadow economy and the standard VAT rate, with a positive impact, and GDP per capita, the share in intracommunity trade, final consumption of restaurant and hotel services, and the number of VAT rates, having a negative impact on the VAT gap.
\end{abstract}

Keywords: tax evasion, tax gap, estimates, determinants of VAT gap, theoretical VAT liability

JEL Classification: H26

\section{Introduction}

The VAT gap is the difference between the theoretical VAT liability and accrued VAT receipts in a respective state and year. Quantifying and analysing VAT gaps has become important for tax administrations in the European Union in recent years due to increasing tax evasion and tax fraud with respect to VAT. A new type of tax evasion known as carousel fraud ${ }^{1}$ has appeared, which is alarming, particularly because VAT has always been considered one of the least vulnerable taxes in terms of tax evasion.

* Univerzity of Economics, Prague (hanazidkova@email.cz). The paper was prepared as one of the outputs of a Research Project of the Faculty of Finance and Accounting at the University of Economics, which is realized within the IGA VŠE F1/2/2013 "Public Finance in Developed Countries".

1 Carousel fraud abuses the VAT exemption for intra-community supplies between EU Member States. The person acquiring the goods in another member state becomes the so-called missing trader, who issues an invoice with VAT to a local customer, and then disappears without paying the output VAT. The local customer claims this VAT from the Financial Authorities as input VAT, and the state budget incurs a loss in this respect. 
Although, the VAT gap is not an only measure of VAT fraud, as it may include VAT not paid as a result of legal tax planning or due to the insolvency of the VAT payer, the quantification of the VAT gap is useful in realizing the size and trend thereof as an indicator of potential VAT evasion. Furthermore, the higher VAT gap could also arise when the tax authorities do not work efficiently. Therefore, the VAT gap is sometimes also used as a measure of the effectiveness of tax collection by the financial authorities, which is not affected by economic changes or changes to VAT rates. The growing size of VAT gap may indicate either a VAT evasion or a low effectiveness of tax collection or both together. Therefore, the policymakers and tax administration should pay appropriate attention to these problems.

VAT revenues are an important source of income for all EU Member States, as shown in Figure 1 below.

Figure 1

\section{Share of VAT in Total Tax Revenues in EU Member States in 2006}

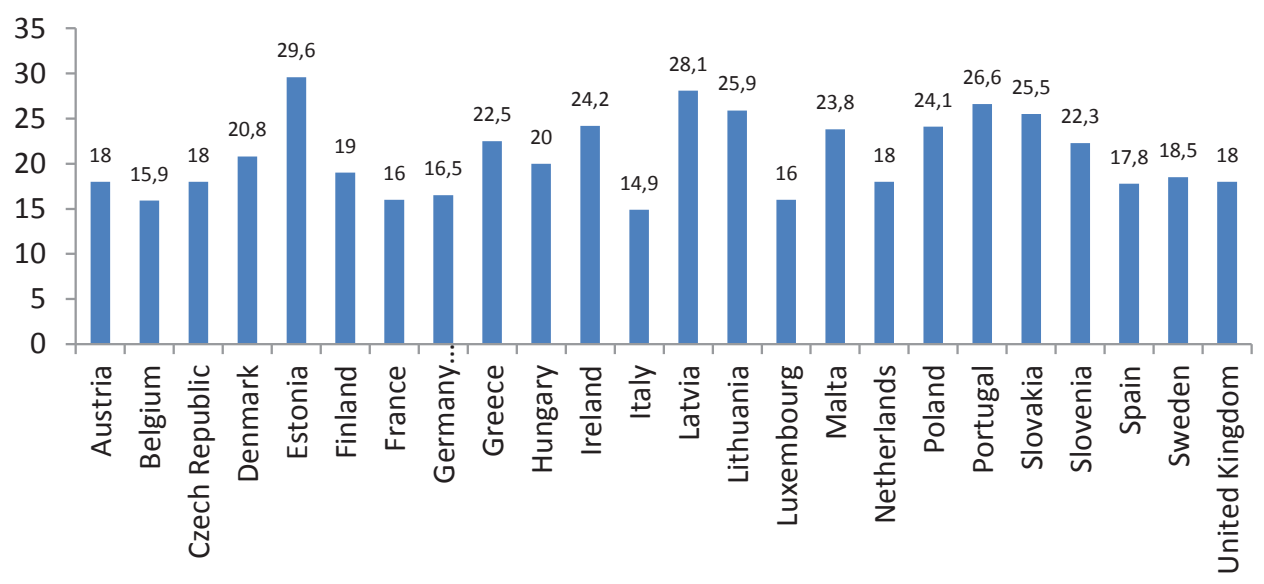

Source: Eurostat, own presentation of data

Finding the nature and causes of the VAT gap is also an issue on which many researchers concentrate. Understanding the factors that influence the VAT gap could potentially help in reducing it by making changes to the VAT system and adjusting VAT policy. However, prior to making any definitive conclusions from analysing the VAT gap and its determinants, it should be noted that the VAT gap figures calculated in various studies could also include mistakes arising from the method used for the computation as discussed in the next part of the article.

The aim of this paper is to further research the determinants of the VAT gap. It will examine the dependence of the VAT gap in 24 EU Member States in the years 2002 and 2006 on various economic, social and tax system factors. Unfortunately, the data 
on the VAT gap for later years are not available for the whole sample of countries ${ }^{2}$. A project "Study to Quantify and Analyse the VAT Gap in the EU-27 Member States" in the years 2007 to 2010 was assigned to the Center for Social and Economic Research ${ }^{3}$. Therefore, we can extend our research based on more up-to-date data in the future.

In contrast to previous works exploring this area, log-form regression models will be used to determine not only the relevant factors influencing the VAT gap, but also the elasticity of the relationships between the variables.

In the first part of the article, the methods for quantifying the VAT gap and existing estimates will be summarized. Further, the econometric studies of the factors influencing either the VAT gap or VAT performance measured by other indicators than the VAT gap will be reviewed. In the second part of the text, explanatory variables will be suggested for the regression analysis, which will be presented in a table, together with hypotheses about the impact thereof on the VAT gap, and with the relevant sources of data. The third part of the paper will show the results of each regression, including comments on the economic interpretation, and comparison with previous literature. Ultimately, in the fourth part, the results will be summarized and discussed.

\section{Review of Literature}

According to Reckon (2009), two different methods are used for calculating the VAT gap. One common method is the so-called "top-down" approach, using macroeconomic data from national accounts to quantify the theoretical VAT liability for the whole economy, and comparing it to the actual VAT receipts of the tax administration. The authors define the theoretical VAT liability as follows: "it includes the VAT applied to the final consumption of households and non-profit organizations, which constitutes the most significant part thereof. Further, the estimated VAT liability contains the intermediate consumption and gross fixed capital formation of institutions and companies that do not have a full right to a VAT deduction. Thus, their input VAT becomes part of the total theoretical VAT liability that should be paid". It should be noted that the theoretical VAT liability only contains the final consumption and other elements needed for its computation which are reported to statistical office in its surveys. The income from the "grey" or "shadow" economy not reported for tax purposes might not be declared to statistical office which would reduce or eliminate the computed VAT gap. However, the statisticians estimate the "grey" economy using an elaborated methodology ${ }^{4}$ to complete the national accounts. Therefore, we can assume that the top-down approach can provide reasonable results on macroeconomic level.

2 The estimates of the VAT gap for further years are reported only for the UK in HMRC (2012) and Slovakia in Novysedlak and Palkovičova (2012).

3 This study should update the VAT gap estimates for 2000-2006 and provide estimates for the VAT gap for the period 2007-2010, as well as expand the scope of the study to include the Member States that were not included in the initial study (Cyprus, Bulgaria and Romania).

4 For more details please, see OECD (2008). 
This "macroeconomic" method is used, for example, by the British tax administration, which not only publishes VAT gap estimates, but also information on the total tax gap annually, the last of which was issued in HMRC (2011). It is also used by the Swedish authorities in Hansson and Wallberg (2008), and by the Slovak Institute for Financial Policy in Novysedlak and Palkovičova (2012). For further analysis, the VAT gap figures for the EU in the years 2002 and 2006 calculated by Reckon (2009) for the European Commission will be used. These numbers were also obtained based on the macroeconomic method described above. It must be pointed out that the results of this method could be biased by various mistakes that can arise due to the fact that the theoretical VAT liability is calculated from macroeconomic aggregated data, and thus the authors must make significant assumptions. For example, they must estimate the share of consumption within one category of product, but subject to different VAT rates, as they only have aggregate numbers from national accounts. It is also important to assess the ratio at which the exempt or partly-exempt companies can recover input VAT, which has an impact on the VAT paid, but not recovered through intermediate consumption. However, the information needed for calculating such proportion is difficult to obtain for all Member States.

The other way of calculating the VAT gap and the tax gap generally is the so-called "bottom-up" approach. The theoretical liability is derived by extrapolating data relating to individual companies or to discovered fraud. This method compiles data from surveys, various studies and some unofficial registers kept by the Financial Authorities. The "bottom-up" approach is used in the United States in calculating the tax gap by the U.S. Internal Revenue Service (1979). The British and Swedish tax administrations also apply it to complete the information on the tax gap, and particularly the structure thereof, which helps to fight against tax evasion more efficiently. This method is usually not used by scholars, as they cannot obtain the relevant information.

As it is mentioned in Reckon (2009): "The empirical work focused on the causes of the VAT gap is hindered by the difficulties in measuring it and the lack of robust estimates for this phenomenon". The authors of the study mention previous research of the determinants of the VAT gap on cross-section observations performed by Agha and Haughton (1996), who in 1987 analyzed 17 OECD countries. They concluded that "a higher VAT rate is associated with lower compliance". They found that a percentage point increase in the VAT rate would reduce the compliance rate by 2.7 percentage points. The other significant factor was the number of VAT rates applied in the state, with each additional VAT rate reducing compliance by 7 percentage points. The last two significant variables were the population and the length of time VAT has been applied in the country: the smaller a country is in terms of population, and the longer the VAT system has been in operation, the more VAT compliance increases.

Christie and Holzner (2006) examined the relationship between an indicator known as "concealed consumption" and chosen factors in the EU Member States in the years 2000 to 2003 . The indicator used was computed from national accounts based 
on a macroeconomic method similar to that described above. They identified the following effects on VAT compliance. A higher weighted average VAT rate reduces VAT compliance. Greater judicial and legal effectiveness increases VAT compliance. Countries where citizens want more power for local authorities tend to have lower levels of VAT compliance. This was explained by the authors in such a way that people prefer more power for authorities if they consider their tax system not to be fair (may be prone to evasion), and in such situation they also do not comply with tax rules. The last significant factor identified was the proportion of GDP from travel revenues, which had a positive impact on VAT compliance.

Reckon (2009), when calculating the VAT gap in the EU Member States, also conducted an econometrical analysis to identify country-specific characteristics that relate to different levels of VAT gap. The variable identified as having the strongest relationship to the size of the VAT gap was the perceived level of corruption in the country. It was implied from the regression that lower perceived corruption is associated with a lower VAT gap. Also, the VAT burden expressed as the theoretical VAT liability divided by GDP had a significant positive relationship with the VAT gap. This would be in line with the limited literature on this topic. However, the authors pointed out that the estimated relationship could be biased by measurement errors in the estimation of the theoretical VAT liability. After taking this risk into account by using an instrumental variable regression, they found no statistically significant relationship between the VAT gap and the VAT burden.

Some studies explored the determinants of some other measures of the revenue productivity of VAT. Aizenman and Jinjirak (2005) focused on the "C-ratio", defined as the ratio of VAT revenue to aggregate consumption, divided by the standard rate of VAT. The $C$-ratio is computed as follows:

$$
C-\text { ratio }=\frac{V R / \text { Consumption }}{r}
$$

Where VR means VAT revenues, Consumption is the final consumption of households, non-profit organizations serving households (further "NPISH") and government, and $r$ stands for the standard rate of VAT. This ratio depends not only on VAT compliance, but also on the "purity" of the VAT system. Therefore, a widespread application of the standard VAT rate without employing any exemptions that distort the VAT neutrality and the non-existence of VAT evasion would lead to a C-ratio equal to 1 . These authors found that the C-ratio falls as the share of the agricultural sector in GDP increases. However, according to Aizenman and Jinjirak (2005), it is not clear if this is caused by lower VAT compliance of farmers, or a lower VAT rate on agricultural products. In this paper, a positive relationship between the openness of the economy and the C-ratio was also identified. This is in accordance with the findings that VAT from imports is easily collected. Further variables increasing the C-efficiency ratio were the GDP per capita and the stability of the political system. 
Bodin et al. (2001) performed an econometrical analysis of the VAT revenue ratio, defined as VAT revenues divided by the potential tax base, and multiplied by the standard VAT rate. The potential tax base "B" is the final consumption (like in the C-efficiency ratio), less VAT revenues, since consumption is reported in national accounts in purchase prices that include VAT. The VRR is calculated as follows:

$$
V R R=\frac{V R}{B \cdot r}
$$

Where $V R$ are VAT revenues, $B$ is the final consumption of households, NPISH and governments, and $r$ is the standard rate. This VAT performance measure is more precise than the C-efficiency ratio, but is similar in terms of meaning, i.e. includes not only the level of VAT compliance, but also the structure of the VAT system. The authors found that with the increase of the VAT rate, the VRR rises, but not proportionally, and the VRR also increases with a higher share in international trade (like in the previously mentioned paper). An interesting factor found by the authors was the difference between the VAT rates applied in the country: the higher the difference, the higher the VRR. This is explained by using the optimal fiscal policy and applying different VAT rates on goods with different demand elasticity. The study also identified the positive relationship between the time for which the VAT system has been established in the country and the VRR. As Bodin et al. (2001) concludes, this could be caused by more experience with the system, but also by the abolishment of various exemptions.

Barbone, Bird, and Vázquez-Caro (2012) focused on the relationship between VAT evasion and the administrative cost of VAT compliance. They concluded that there is a correlation between the tax gap in the EU Member States and VAT administrative costs. Bird, Martinez-Vazquez, and Torgler (2004) concentrated on social and institutional factors influencing tax evasion generally (not just VAT). They explored developing countries, and not the EU Member States. They studied, for example, the index of government effectiveness, the index of risk for foreign investors, the regulation of starting a business in the country, the tax morals of the population, income inequality, and fiscal decentralization.

\section{Materials and Methods}

The data on the VAT GAP is taken from the study of Reckon (2009). Table 1 below shows the VAT gap for years 2002 and 2006 in 24 EU countries. In the first column of each year, the VAT gap is expressed in relative terms to the theoretical VAT liability. This variable measures the proportion of theoretical liability that is not remitted. The second and third columns include the total VAT gap. 
Table 1

Total and Relative VAT Gap in 24 Member States in Years 2002 and 2006

\begin{tabular}{|c|c|c|c|c|c|c|}
\hline \multirow[b]{2}{*}{ Member State } & \multicolumn{3}{|c|}{2002} & \multicolumn{3}{|c|}{2006} \\
\hline & $\begin{array}{l}\text { Relative } \\
\text { VAT Gap }\end{array}$ & $\begin{array}{l}\text { Total Gap in } \\
\text { Mil. of Local } \\
\text { Currency }\end{array}$ & $\begin{array}{l}\text { Total Gap in } \\
\text { Mil. of EUR }\end{array}$ & $\begin{array}{l}\text { Relative } \\
\text { VAT Gap }\end{array}$ & $\begin{array}{l}\text { VAT Gap in } \\
\text { Mil. of Local } \\
\text { Currency }\end{array}$ & $\begin{array}{l}\text { Total VAT Gap } \\
\text { in Mil. of EUR }\end{array}$ \\
\hline Austria & $10 \%$ & 2,006 & 2,006 & $14 \%$ & 3,108 & 3,108 \\
\hline Belgium & $13 \%$ & 2,684 & 2,684 & $11 \%$ & 2,791 & 2,791 \\
\hline Czech Republic & $16 \%$ & 30,494 & 857 & $18 \%$ & 47,468 & 1,710 \\
\hline Denmark & $8 \%$ & 11,129 & 1,493 & $4 \%$ & 1,051 & 141 \\
\hline Estonia & $15 \%$ & 1,855 & 118 & $8 \%$ & 1,731 & 111 \\
\hline Finland & $4 \%$ & 530 & 530 & $5 \%$ & 758 & 758 \\
\hline France & $7 \%$ & 8,637 & 8,637 & $7 \%$ & 9,800 & 9,800 \\
\hline Germany & $13 \%$ & 20,884 & 20,884 & $10 \%$ & 16,965 & 16,965 \\
\hline Greece & $20 \%$ & 2,973 & 2,973 & $30 \%$ & 6,563 & 6563 \\
\hline Hungary & $25 \%$ & 439,842 & 1,691 & $23 \%$ & 546,898 & 2,176 \\
\hline Ireland & $3 \%$ & 247 & 247 & $2 \%$ & 241 & 241 \\
\hline Italy & $24 \%$ & 25,673 & 25,673 & $22 \%$ & 26,337 & 26,337 \\
\hline Latvia & $32 \%$ & 178 & 48 & $22 \%$ & 263 & 76 \\
\hline Lithuania & $18 \%$ & 841 & 1,504 & $22 \%$ & 1,760 & 2,514 \\
\hline Luxembourg & $5 \%$ & 71 & 71 & $1 \%$ & 20 & 20 \\
\hline Malta & $4 \%$ & 5 & 12 & $11 \%$ & 23 & 54 \\
\hline Netherlands & $9 \%$ & 3,259 & 3,259 & $3 \%$ & 1,381 & 1,381 \\
\hline Poland & $20 \%$ & 14,705 & 3,669 & $7 \%$ & 6,457 & 1,611 \\
\hline Portugal & $7 \%$ & 859 & 859 & $4 \%$ & 614 & 614 \\
\hline Slovakia & $27 \%$ & 28,727 & 675 & $28 \%$ & 48,848 & 1,312 \\
\hline Slovenia & $13 \%$ & 287 & 287 & $4 \%$ & 116 & 116 \\
\hline Spain & $12 \%$ & 5,790 & 5,790 & $2 \%$ & 1,418 & 1,418 \\
\hline Sweden & $4 \%$ & 9,482 & 1,123 & $3 \%$ & 7,468 & 807 \\
\hline United Kingdom & $17 \%$ & 14,282 & 23,433 & $17 \%$ & 18,390 & 30,173 \\
\hline
\end{tabular}

Source: Reckon (2009), own calculations of VAT gap in euro based on exchange rates from the Eurostat.

The relative tax gap varied from $3 \%$ in Ireland to $32 \%$ in Latvia in 2002, and from $1 \%$ in Luxemburg to $30 \%$ in Greece for the year 2006. The descriptive statistics of dependent variables are included in Tables 2 and 3 below. 
Table 2

Descriptive Statistics of Dependent Variables in 2002

\begin{tabular}{|l|r|r|r|r|c|c|}
\hline Explanatory Variable & Average & Median & Minimum & Maximum & $\begin{array}{c}\text { Standard } \\
\text { deviation }\end{array}$ & $\begin{array}{c}\text { Coefficient } \\
\text { of variation }\end{array}$ \\
\hline RELGAP/\% & 0.14 & 0.13 & 0.03 & 0.32 & 0.08 & 0.59 \\
\hline $\begin{array}{l}\text { GAPLOCAL/ Mil. of } \\
\text { Local Currency }\end{array}$ & 26,060 & 3,116 & 5.00 & 439,842 & 88,659 & 3.40 \\
\hline GAP/Mil. of EUR & 4,526 & 1,473 & 13.10 & 25673 & 7,565 & 1.67 \\
\hline
\end{tabular}

Source: Own calculation.

Table 3

Descriptive Statistics of Dependent Variables in 2006

\begin{tabular}{|l|r|r|r|r|r|c|}
\hline $\begin{array}{l}\text { Explanatory } \\
\text { Variable }\end{array}$ & Average & Median & Minimum & Maximum & $\begin{array}{c}\text { Standard } \\
\text { Deviation }\end{array}$ & $\begin{array}{c}\text { Coefficient of } \\
\text { Variation }\end{array}$ \\
\hline RELGAP/\% & 0.12 & 0.09 & 0.01 & 0.30 & 0.09 & 0.78 \\
\hline $\begin{array}{l}\text { GAPLOCAL/Mil. of } \\
\text { Local Currency }\end{array}$ & 31,270 & 2,276 & 20.0000 & 546,898 & 110,700 & 3.54 \\
\hline GAP/Mil. of EUR & 4,611 & 1,400 & 20.0000 & 30,173 & 8,240 & 1.79 \\
\hline
\end{tabular}

Source: Own calculation.

The analysis will pursue two alternative models based on cross-country OLS regression in the years 2002 and 2006. The econometric methods used are based on Wooldridge (2002). In the first model, the dependent variable in the analysis will be the relative VAT gap. The explanatory variables will also be entered in relative form to keep their variability at a reasonable level. The second model will explore the elasticity of the relationship between the VAT GAP and the explanatory variables. Therefore, the data will enter this model in log-forms.

Table 4 lists the relevant factors chosen based on an analysis of the literature summarized above and own considerations. It also contains a brief description of the reason for their inclusion and the source from which they were obtained. 
Table 4

\section{Candidate Explanatory Variables}

\begin{tabular}{|c|c|c|c|}
\hline $\begin{array}{l}\text { Variable/Abbreviation } \\
\text { in Statistical Model }\end{array}$ & $\begin{array}{l}\text { Underlying Factor } \\
\text { Captured by Variable }\end{array}$ & $\begin{array}{c}\text { Hypothesis of } \\
\text { Relationship with VAT Gap }\end{array}$ & Source of Data \\
\hline GDP per Capita/GDPinhab & $\begin{array}{l}\text { Wealth/level of } \\
\text { development }\end{array}$ & Decreases & $\begin{array}{l}\text { Eurostat (national } \\
\text { accounts) }\end{array}$ \\
\hline Population/Pop & Country size & Increases & Eurostat \\
\hline GDP/GDP & Size of economy & Decreases & Eurostat \\
\hline GINI Coefficient/GINI & Income inequality & Increases & $\begin{array}{l}\text { Eurostat (indicators } \\
\text { of life conditions) }\end{array}$ \\
\hline $\begin{array}{l}\text { Household Final Consumption } \\
\text { of Restaurants and Hotel } \\
\text { Services (percentage of total } \\
\text { consumption)/REST }\end{array}$ & $\begin{array}{l}\text { Proxy for effect } \\
\text { of tourism }\end{array}$ & Decreases & $\begin{array}{l}\text { Eurostat (national } \\
\text { accounts) }\end{array}$ \\
\hline $\begin{array}{l}\text { Share of Country in Intra- } \\
\text { community Trade/SHAREIT }\end{array}$ & $\begin{array}{l}\text { Exposure to carousel } \\
\text { fraud/openness } \\
\text { of economy }\end{array}$ & $\begin{array}{c}\text { Increases if carousel fraud is } \\
\text { in place/decreases if impact } \\
\text { of openness of economy } \\
\text { prevails }\end{array}$ & $\begin{array}{l}\text { Eurostat (national } \\
\text { accounts) }\end{array}$ \\
\hline $\begin{array}{l}\text { Share of Final Consumption } \\
\text { of Households and NPISH } \\
\text { on GDP/FConGDP }\end{array}$ & $\begin{array}{l}\text { Size of potential VAT } \\
\text { base }\end{array}$ & Increases & $\begin{array}{l}\text { Eurostat (national } \\
\text { accounts) }\end{array}$ \\
\hline $\begin{array}{l}\text { Final Consumption per Capita/ } \\
\text { FCinhab }\end{array}$ & $\begin{array}{l}\text { Size of potential VAT } \\
\text { base and also level } \\
\text { of development }\end{array}$ & $\begin{array}{c}\text { Increases with size of tax } \\
\text { base/decreases with level of } \\
\text { development }\end{array}$ & $\begin{array}{l}\text { Eurostat (national } \\
\text { accounts) }\end{array}$ \\
\hline Standard VAT Rate/VATR & VAT burden & Increases & $\begin{array}{l}\text { European Commission } \\
\text { (Taxation Trends in EU) }\end{array}$ \\
\hline $\begin{array}{l}\text { Implicit Tax Rate } \\
\text { of Consumption (revenue from } \\
\text { all consumption taxes divided } \\
\text { by total consumption)/ITCR }\end{array}$ & Tax burden & Increases & $\begin{array}{l}\text { European Commission } \\
\text { (Taxation Trends in EU) }\end{array}$ \\
\hline $\begin{array}{l}\text { VAT Revenues as Percentage } \\
\text { of GDP/VATonGDP }\end{array}$ & $\begin{array}{c}\text { Tax quota } \\
\text { (VAT burden) }\end{array}$ & Increases & $\begin{array}{l}\text { European Commission } \\
\text { (Taxation Trends in EU) }\end{array}$ \\
\hline $\begin{array}{l}\text { VAT as Percentage of Total Tax } \\
\text { Revenues/VATonREV }\end{array}$ & $\begin{array}{l}\text { Significance of VAT } \\
\text { in tax structure }\end{array}$ & Increases & $\begin{array}{l}\text { European Commission } \\
\text { (Taxation Trends in EU) }\end{array}$ \\
\hline $\begin{array}{l}\text { VAT Registration Threshold/ } \\
\text { TRESH }\end{array}$ & $\begin{array}{c}\text { Scope of application } \\
\text { of VAT }\end{array}$ & Increases & $\begin{array}{l}\text { European Commission, } \\
\text { Publications of global } \\
\text { tax advisory firms }\end{array}$ \\
\hline Number of Rates/NUMRATES & $\begin{array}{l}\text { Complexity of VAT } \\
\text { system/fiscal policy }\end{array}$ & $\begin{array}{l}\text { Increases due to complexity/ } \\
\text { decreases if impact of more } \\
\text { effective taxation of goods } \\
\text { with lower demand elasticity } \\
\text { prevails }\end{array}$ & $\begin{array}{l}\text { European Commission } \\
\text { (VAT rates) }\end{array}$ \\
\hline $\begin{array}{l}\text { Share of Shadow Economy/ } \\
\text { Stinek }\end{array}$ & $\begin{array}{c}\text { Significance of shadow } \\
\text { economy }\end{array}$ & Increases & Schneider (2012) \\
\hline $\begin{array}{l}\text { Perception of Corruption } \\
\text { Index/CPI }\end{array}$ & $\begin{array}{l}\text { Level of corruption, } \\
\text { confidence of people } \\
\text { in public sector }\end{array}$ & $\begin{array}{l}\text { Decreases (higher CPI } \\
\text { indicates less corruption } \\
\text { in country) }\end{array}$ & $\begin{array}{c}\text { Transparency } \\
\text { International Report }\end{array}$ \\
\hline
\end{tabular}

Source: Own choice based on literature in Part 2.

Descriptive statistics of the explanatory variables are shown in Tables 5 and 6 below: 
Table 5

Descriptive Statistics of Explanatory Variables in 2002

\begin{tabular}{|l|r|r|r|r|r|r|}
\hline Explanatory Variable & \multicolumn{1}{|c|}{ Average } & \multicolumn{1}{c|}{ Median } & \multicolumn{1}{c|}{ Minimum } & Maximum & $\begin{array}{c}\text { Standard } \\
\text { Deviation }\end{array}$ & $\begin{array}{c}\text { Coefficient } \\
\text { of Variation }\end{array}$ \\
\hline ITRC/\% & 21.03 & 19.45 & 15.50 & 33.70 & 4.35 & 0.20 \\
\hline CPI/(0-10) & 6.51 & 6.38 & 3.70 & 9.70 & 1.99 & 0.30 \\
\hline $\begin{array}{l}\text { Pop/Number of } \\
\text { People }\end{array}$ & $1.89252 \mathrm{e}+007$ & $9.54199 \mathrm{e}+006$ & 394,641 & $8.24403 \mathrm{e}+007$ & $2.37169 \mathrm{e}+007$ & 1.25319 \\
\hline SHAREIT/\% & 0.04 & 0.02 & 0.00 & 0.19 & 0.05 & 1.21 \\
\hline FinalCon/Mil. of EUR & 239,549 & 88,087 & 2,863 & $1.24058 \mathrm{e}+006$ & 366,901 & 1.53 \\
\hline GDP/Mil. of EUR & 410,787 & 150,130 & 4,556 & $2.13220 \mathrm{e}+006$ & 610,568 & 1.49 \\
\hline FConGDP/\% & 0.57 & 0.57 & 0.42 & 0.73 & 0.07 & 0.13 \\
\hline VATonGDP/\% & 7.22 & 7.20 & 5.80 & 9.60 & 0.94 & 0.13 \\
\hline GDPihab/EUR & 19,740 & 20,322 & 4,184 & 54,030 & 12,653 & 0.64 \\
\hline VATonREV/\% & 20,0708 & 19.65 & 14.70 & 27.00 & 3.47 & 0.17 \\
\hline FCinhab/EUR & 10,603 & 11,913 & 2,624 & 22,642 & 5,850 & 0.55 \\
\hline VATR/\% & 19,796 & 19.80 & 15.00 & 25.00 & 2.97 & 0.15 \\
\hline NUMRATES/Number & 2.67 & 3.00 & 1.00 & 5.00 & 0.81 & 0.31 \\
\hline REST/\% & 8.18 & 6.80 & 2.90 & 18.10 & 3.99 & 0.49 \\
\hline TRESH/EUR & 27,936 & 21,664 & 0.10 & 81,843 & 24,818 & 0.89 \\
\hline GINI/(0-100) & 28.61 & 27.85 & 22.00 & 37.00 & 4,03747 & 0,14 \\
\hline Stinek/\% & 0.19 & 0.18 & 0.07 & 0.38 & 0.08 & 0.42 \\
\hline
\end{tabular}

Source: Own calculation.

Table 6

\section{Descriptive Statistics of Explanatory Variables in 2006}

\begin{tabular}{|c|c|c|c|c|c|c|}
\hline $\begin{array}{l}\text { Explanatory } \\
\text { Variable/Units }\end{array}$ & Average & Median & Minimum & Maximum & $\begin{array}{l}\text { Standard } \\
\text { Deviation }\end{array}$ & $\begin{array}{l}\text { Coefficient } \\
\text { of Variation }\end{array}$ \\
\hline ITRC/\% & 21.95 & 20.40 & 16.00 & 34.20 & 4.42 & 0.20 \\
\hline $\mathrm{CPI} /(0-10)$ & 6.80 & 6.75 & 3.70 & 9.60 & 1.81 & 0.27 \\
\hline Pop/People & $1.92965 \mathrm{e}+007$ & $9.56217 e+006$ & 405,006 & $8.24380 e+007$ & $2.41604 \mathrm{e}+007$ & 1.25 \\
\hline SHAREIT/\% & 0.04 & 0.02 & 0.00 & 0.19 & 0.05 & 1.17 \\
\hline FinalCon/Mil. of EUR & 277,212 & 105,100 & 3,303 & $1.33954 \mathrm{e}+006$ & 410,256 & 1.48 \\
\hline GDP/Mil. of EUR & 481,789 & 193,595 & 5,068 & $2.31390 e+006$ & 687,804 & 1.43 \\
\hline FConGDP/\% & 0.56 & 0.56 & 0.33 & 0.70 & 0.08 & 0.15 \\
\hline VATonGDP/\% & 7.63 & 7.60 & 5.80 & 10.30 & 1.06 & 0.14 \\
\hline GDPihab/EUR & 23,883 & 23,850 & 7,000 & 71,800 & 15,211 & 0.64 \\
\hline VATonREV/\% & 20.97 & 20.15 & 14.90 & 29.60 & 4.20 & 0.20 \\
\hline FCinhab/EUR & 17,250 & 18,450 & 5,800 & 35,100 & 8,914 & 0.52 \\
\hline VATR/ $\%$ & 19.55 & 19.30 & 15.00 & 25.00 & 2.46 & 0.13 \\
\hline NUMRATES/Number & 2.63 & 3.00 & 1.00 & 5.00 & 0.82 & 0.31 \\
\hline REST $/ \%$ & 8.11 & 7.05 & 2.90 & 18.20 & 3.69 & 0.45 \\
\hline TRESH/EUR & 27,936 & 21,664 & 0.10 & 81,843 & 24,818 & 0.89 \\
\hline GINI/(0-100) & 29.70 & 27.95 & 23.70 & 39.20 & 4.48 & 0.15 \\
\hline Stinek/\% & 0.19 & 0.19 & 0.10 & 0.31 & 0.07 & 0.35 \\
\hline
\end{tabular}

Source: Own calculation. 
The general form of the regression models used for the surveyed years across the Member States are as follows:

$$
\operatorname{VAT} \operatorname{gap}(i)=a+b_{1} X_{1}(i)+\ldots . . b_{k} X_{k}(i)+e(i)
$$

In this equation, $i$ denotes the member state, $a$ is a constant, $b$ coefficients are the slopes on explanatory variables, $X$ and $e$ is the model disturbance term.

A general-to-specific approach was used to identify those variables that exhibit a not insignificant relationship with the VAT gap share. This approach involves starting with the most general model, including all the candidate explanatory variables. Then the variables are dropped from the model, one at a time, starting with the one that has the highest $p$ value. The final model for each year should contain only variables significant at a level of 90 percent or more.

In each model identified by statistical inference, the econometric tests were performed to ascertain whether the error terms are independently and identically distributed. First, the normality of residuals was tested using the Chi square goodness-of-fit test. Due to the cross-sectional character of data, White's test for heteroskedasticity was carried out. Also the test for multi-colinearity analysing the correlation matrix of explanatory variables was conducted. In all models presented below, the explanatory variables only correlated to an acceptable level. The error terms were normally distributed and homoskedastic.

Finally, the Ramsay reset test for the model specification was performed. The null hypothesis that the added parameters of cube and square added fitted values to the regression have no significant relationship with the dependent variable was confirmed (p-value equal to 0.235 ).

\section{Results}

The following tables report the results of two alternative models for each year.

Table 7

Model with Relative Variables for Year 2002

\begin{tabular}{|l|c|c|c|c|}
\hline \multirow{2}{*}{ Dependent Variable } & \multicolumn{2}{|c|}{ Relative VAT GAP } & \multicolumn{2}{|c|}{} \\
\cline { 2 - 5 } & Coefficient & Standard Error & T-stat. & P-value \\
\hline Constant & -0.22 & 0.16 & -1.37 & 0.19 \\
\hline Final Consumption on GDP & 0.49 & 0.20 & 2.39 & $0.03^{\text {** }}$ \\
\hline VAT Revenues on GDP & -0.04 & 0.02 & -2.32 & $0.03^{\text {** }}$ \\
\hline Standard VAT Rate & 0.01 & 0.01 & 2.67 & $0.02^{\text {** }}$ \\
\hline Share of Shadow Economy on GDP & 0.39 & 0.18 & 2.24 & $0.04^{\text {** }}$ \\
\hline
\end{tabular}

\begin{tabular}{|l|c|l|c|}
\hline Coefficient of Determination $R^{2}$ & 0.56 & $\begin{array}{l}\text { Adjusted Coefficient of } \\
\text { Determination - Adjust. } R^{2}\end{array}$ & 0.46 \\
\hline$F(4,19)$ & 5.93 & P-value(F) & 0.00 \\
\hline
\end{tabular}


For the year 2002, the final consumption on GDP, the standard VAT rate and the share of the shadow economy were positive, indicating that the relative VAT GAP is increasing in these variables. The variable VAT revenues on GDP representing the tax quota or overall tax burden have a negative effect on the VAT gap. All of the coefficient estimates have the expected sign, except for the negative coefficient identified for VAT on GDP. According to the theory, the VAT burden should positively influence the VAT gap due to the hypothesis that a higher tax burden serves as a greater inducement to tax payers to commit tax evasion. However, the above result is not completely contradictory to the findings of previous researchers.

For example, Reckon (2009), which performed the most recent econometric analysis in this area, at first found a significant positive relationship between the VAT burden and the VAT gap, but they considered this finding to be biased by possible mistakes in the computation of the theoretical VAT liability, which was used as the variable representing the VAT burden. Therefore, they used an instrumented explanatory variable for VAT burden based on the standard VAT rate and government final consumption. Then, their model yielded a negative relationship between the VAT burden and the VAT gap, which was not statistically significant.

The findings of the model could be influenced by the fact that the variable VAT revenues on GDP depends not only on the rate of taxation (average VAT rate in the economy) but also on final consumption of household representing major part of the tax base. The changes in VAT rate could influence the final consumption. For example, the VAT revenues were lower comparing to what was expected by the experts of the Ministry of Finance in the Czech Republic in 2012 due to a significant drop in the final consumption of household. It was frequently interpreted as a result of the increase of the reduced rate from $10 \%$ to $14 \%$. Nevertheless, the example of the Czech Republic does not necessarily prove any causality between the VAT rate and final consumption. There were probably also other social and economic reasons of the decrease of consumption.

Usually, the final consumption of households is considered to be quite stable element of GDP. Therefore, its positive relationship with the VAT gap could be explained by the increasing probability of VAT evasion with the increasing tax base. Assuming a stable proportion of final consumption on GDP, the variable VAT revenues on GDP represents the rate of taxation. Its negative influence on VAT gap could probably be explained by higher tax morals and efficiency of the public sector in countries with higher VAT rates (and proportion of VAT revenues on GDP). This could be the case of Scandinavian countries.

This regression model accounts for only $46 \%$ of the variance of the data. The variables identified are significant at the $95 \%$ level. Although the model does not have the ideal statistical parameters, it is the best model using the relative variables found in the available cross-section data for the year 2002 . 
Table 8

Model with Log-forms of Variables for Year 2002

\begin{tabular}{|l|c|c|c|c|}
\hline \multirow{2}{*}{ Dependent Variable } & \multicolumn{3}{|c|}{ Log of Total VAT Gap in Euro } & \\
\cline { 2 - 5 } & Coefficient & Standard Error & T-stat. & P-value \\
\hline Constant & 0.64 & 0.74 & 0.86 & 0.40 \\
\hline Log of Final Consumption & 1.18 & 0.09 & 12.96 & $<0.00^{* * *}$ \\
\hline Log of GDP per Capita & -0.79 & 0.21 & -3.75 & $0.00^{* * *}$ \\
\hline
\end{tabular}

\begin{tabular}{|l|c|l|c|}
\hline Coefficient of Determination $R^{2}$ & 0.90 & $\begin{array}{l}\text { Adjusted Coefficient } \\
\text { of Determination - Adjust. } \mathrm{R}^{2}\end{array}$ & 0.89 \\
\hline $\mathrm{F}(2,21)$ & 90.97 & P-value $(\mathrm{F})$ & $4.53 \mathrm{e}-11$ \\
\hline
\end{tabular}

The model using the log-forms of variables finds, like the previous model, the positive influence of final consumption on the VAT gap. As final consumption represents the tax base for VAT, the increase thereof naturally results in higher VAT revenue. At the same time, a one percentage rise in final consumption coincides with an increase of the total VAT gap by $1.18 \%$. A second significant explanatory variable identified in this model is the GDP per inhabitant, the increase of which by one percentage lowers the total VAT gap by $0.78 \%$. This result corresponds with previous findings of Aizenman and Jinjirak (2005), who found a positive association between GDP per capita and the C-efficiency ratio. This is explained by the fact that more developed countries achieve better VAT compliance.

This model explains $88 \%$ of the variance of the data. Both explanatory variables identified are significant at the $99 \%$ level, which denotes the good explanatory power of the model.

Table 9

Model with Relative Variables for Year 2006

\begin{tabular}{|l|c|c|c|c|}
\hline \multirow{2}{*}{ Dependent Variable } & \multicolumn{3}{|c|}{ Relative VAT GAP } & \\
\cline { 2 - 5 } & Coefficient & $\begin{array}{c}\text { Standard } \\
\text { Error }\end{array}$ & T-stat. & P-value \\
\hline Constant & 0.35 & 0.17 & 2.03 & $0.06^{*}$ \\
\hline Share of Intra-community Trade & -0.78 & 0.32 & -2.46 & $0.02^{* *}$ \\
\hline Final Consumption on GDP & 0.78 & 0.16 & 4.73 & $0.0002^{* * *}$ \\
\hline VAT Revenues on GDP & -0.06 & 0.02 & -3.76 & $0.001^{* * *}$ \\
\hline Number of VAT Rates & -0.03 & 0.02 & -1.87 & $0.08^{*}$ \\
\hline $\begin{array}{l}\text { Share of Household Final } \\
\begin{array}{l}\text { Consumption on Restaurant and } \\
\text { Hotel Services }\end{array}\end{array}$ & -0.01 & 0.004 & -2.01 & $0.06^{*}$ \\
\hline
\end{tabular}

\begin{tabular}{|l|c|l|c|}
\hline $\begin{array}{l}\text { Coefficient of } \\
\text { Determination } \mathrm{R}^{2}\end{array}$ & 0.63 & $\begin{array}{l}\text { Adjusted Coefficient of } \\
\text { Determination - Adjust. } \mathrm{R}^{2}\end{array}$ & 0.52 \\
\hline $\mathrm{F}(5,18)$ & 6.03 & P-value $(\mathrm{F})$ & 0.002 \\
\hline
\end{tabular}


After analysing the 2006 data set, the best model with relative indicators includes the share in intra-community trade, VAT revenues on GDP, the number of VAT rates and the share of household final consumption on restaurant and hotel services, with the coefficient being negative, and final consumption on GDP entering positively into the regression. In contrast to the year 2002, the standard VAT rate and the share of the shadow economy have not proved significant. On the other hand, the 2006 model shows that the higher the share in intra-community trade is, the lower the relative VAT gap is, and the impact of the number of VAT rates and the final consumption of restaurant and hotel services also has the same impact on the VAT gap. The newly identified relationships do not contravene previous findings. Although intra-community trade was expected to increase the VAT gap due to higher vulnerability to carousel fraud, it could also represent the openness of the economy, which raised the effectiveness of VAT performance in Bodin et al. (2001) referred to above. Carousel fraud was not as widespread in 2006 as it became in subsequent years. It would be interesting to see if the share in intracommunity trade had a coefficient with a different sign in more recent years.

Previous papers pointed to the ambivalent influence of the number of VAT rates on the VAT gap. Agha and Haughton (1996) found the negative impact of the number of VAT rates on the VAT performance, which conforms to the hypothesis that the more difficult the VAT system is, the lower VAT compliance is. On the other hand, Bodin et al. (2001) reached an interesting conclusion that the difference between the VAT rates increases the VAT revenue ratio. In our model, the variable for the number of VAT rates enters negatively, indicating a decrease in the relative VAT gap with more statutory VAT rates in the country. The coefficient is significant only at the $90 \%$ level, so we should be careful when reaching any final conclusions on the basis thereof.

The share of the final consumption of households spent on restaurant services and hotels also has a negative effect on the relative VAT gap, and the coefficient is also statistically less significant (only at the $90 \%$ level), but the link found corresponds with the findings of Christie and Holzner (2006), who explain it by lower tax evasion in the tourism industry. This explanation does not seem particularly realistic, as cash payments are quite usual in hotels and restaurants, so revenues can easily be concealed. This, at the first sight illogical result, could stem from the fact that concealed cash payments are not measured even by the statistical office and is not estimated as a "grey" economy during the completion of national accounts. Then the VAT gap arising from such cash payments would not be identified. On the other hand, the countries with high ratio of tourism industry to their GDP and at the same time low VAT gap (e.g. Spain or Portugal) could use fiscal cash registers to avoid the tax fraud caused by understating of revenues in such exposed economic fields.

The model accounts for $52 \%$ of the variance of the data. The variables VAT on GDP and final consumption, which were also identified in the model for the 2002 data, are significant at the $99 \%$ level. The share of intra-community trade is significant at the $95 \%$ level and the remaining variables are significant only at the $90 \%$ level, as already discussed. 
Table 10

Model with Log-form Variables for Year 2006

\begin{tabular}{|l|c|c|c|c|}
\hline \multirow{2}{*}{ Dependent Variable } & \multicolumn{3}{|c|}{ Log of Total VAT Gap in Euro } & \\
\cline { 2 - 5 } & Coefficient & Standard Error & T-stat. & P-value \\
\hline Constant & 5.77 & 2.04 & 2.82 & $0.01^{* *}$ \\
\hline Log of Final Consumption & 1.07 & 0.13 & 8.31 & $<0.00001^{* * *}$ \\
\hline Log of VAT Revenues on GDP & -3.10 & 1.48 & -2.10 & $0.05^{* *}$ \\
\hline Log of GDP per Capita & -1.24 & 0.31 & -3.97 & $0.0008^{* * *}$ \\
\hline
\end{tabular}

\begin{tabular}{|l|c|l|c|}
\hline Coefficient of Determination $R^{2}$ & 0.82 & $\begin{array}{l}\text { Adjusted Coefficient of Determination - } \\
\text { Adjust. } R^{2}\end{array}$ & 0.80 \\
\hline$F(3,20)$ & 31.24 & P-value(F) & $9.60 \mathrm{e}-08$ \\
\hline
\end{tabular}

The last model shows the elasticity of relationships found for the year 2006 using the log-forms of variables. The regression indicates that if final consumption increases by one percentage, the total VAT gap also increases, but slightly more, by $1.07 \%$. A one percent rise in the share of VAT on GDP reduces the total VAT Gap by $3.095 \%$. And finally, if GDP per capita rises by one percent, the total VAT gap falls by $1.24 \%$. All these variables were found and commented on in previous models. The model explains $79 \%$ of the variability of the data, and all variables apart from VAT on GDP are significant at the $99 \%$ level.

\section{Discussion}

In both examined years, the relative VAT gap was higher, with higher final consumption. In models using relative variables, if the final consumption on GDP rose by one percentage point, the relative VAT gap increased by 0.49 percentage points in 2002, and 0.78 percentage points in 2006 . The log-form model revealed the elasticity of this relation. If final consumption increased by $1 \%$, the total VAT gap rose by $1.18 \%$ in 2002 and $1.07 \%$ in 2006.

In three of the models presented above, the VAT on GDP proved to be a significant factor reducing the VAT GAP. In 2002, a one percentage point rise in the share of VAT on GDP reduced the relative VAT gap by 0.038 percentage points. In 2006, if the VAT on GDP increased by one percentage point, the relative VAT gap fell by 0.06 percentage points. In the log-form model for 2006, the rise of VAT on GDP by one percentage caused a reduction of the total VAT gap by $3.095 \%$.

This result is not entirely in line with previous literature and the hypothesis that a higher tax burden should lead to higher tax evasion. However, the recent study of Reckon (2009) did not find any significant relationship between the VAT burden and the VAT gap, as already discussed. Also, Barbone (2012, p. 51) mentions that the connection 
between tax burden and tax evasion was ascertained in older studies, whereas in more recent studies, the "institutional variables capturing the culture and attitudes towards the state have begun to appear. The newer studies suggest that countries with better citizenstate relations tend to have higher tax ratios than those in which unhappy citizens are less prone to fulfill their tax obligations".

It would also be interesting to explore a potential non-linear relation between VAT rate and VAT gap. Logically, the VAT compliance could fall more than proportionally with increasing VAT rates. However, all studies relating to this topic and referred in this paper use the linear regression. Further research in this area could be focused on the non-linearity of this relationship.

No studies have yet focused on cultural factors in respect of the VAT gap, and compliance specifically. Therefore, it would be interesting to include explanatory variables from this field into the regression in further research.

Other variables explaining the size of the VAT gap identified in the regressions were the share of the shadow economy and the standard VAT rate, which were positive, indicating that the higher these variables are, the higher the VAT gap is. On the other hand, GDP per capita, the share in intra-community trade, final consumption of restaurant and hotel services and the number of VAT rates have a negative impact on the VAT gap, meaning that if they increase, the VAT gap falls.

Based on the above findings, it could be inferred that states with a high share of final consumption of households on GDP, such as, for example, Greece, Latvia, Lithuania, Portugal, Poland, Malta and the United Kingdom (with more than a $60 \%$ share of final consumption on GDP), should concentrate on the problem of VAT evasion and try to allocate more resources to VAT audits and increasing VAT compliance. On the other hand, to reduce VAT evasion, it is probably not necessary to keep the VAT burden low. Such countries as Sweden, with a $8.9 \%$ share of VAT in GDP, or Denmark, with a $10.3 \%$ proportion of VAT in GDP, both also having the EU highest standard rates amounting to $25 \%$ report low VAT gaps.

However, it should be noted that the factors identified in this paper are based on rather outdated estimates of the VAT gap from the years 2002 and 2006. Using data on the VAT gap from later years, could result in slightly different findings. In response to the economic crisis in 2008, the governments of EU Member States often increased the VAT rates. This increase together with other social and economic factor could result in changes in proportion of final consumption to GDP and other variables important for the VAT gap. Therefore, the results of the models above should be used as a basis for further discussion and it should be noted that they are potentially subject to change depending on new economic conditions. 


\section{References}

Aizenman, J., Jinjarak, Y. (2005), "The Collection Efficiency of Value Added Tax: Theory and International Evidence", [citation: 2012-08-26]. Available at: http://escholarship.org/uc/ item/42d103zh\#page-1.

Agha, A., Haughton, J. (1996), "Designing VAT Systems: Some Efficiency Considerations." The Review of Economics and Statistics, Vol. 78, No. 2, pp. 303-308.

Barbone, L., Bird, R. M., Vazquez-Caro, J. (2012), "The Costs of VAT: A Review of the Literature." CASE Network Reports No. 106, pp. 2-66.

Bird, R. M., Martinez-Vasquez, Torgler, B. (2004), "Societal Institutions and Tax Effort in Developing Countries." SSRN eLibrary, Available at: http://papers.ssrn.com/sol3/papers. cfm?abstract_id=662081.

Bodin, J. P., Ebrill, E. P., Keen, M., Summers, V. P. (2001), The Modern VAT. International Monetary Fund.

European Commission (2012), Taxation Trends in the EU. Luxembourg: Publications Office of the European Union. [Citation 11.11. 2012]. Available at: http://ec.europa.eu/taxation_customs/ resources/documents/taxation/gen_info/economic_analysis/tax_structures/2012/report.pdf.

Hansson, A., Wallberg, K. (2008), Tax Gap Map for Sweden. Swedish National Tax Agency, [Citation 15.12. 2011] Available at: http://www.skatteverket.se/ download/18.225c96e811ae46c823f800014872/Report_2008_1B.pdf

HM Customs and Excise (2011), Measuring Tax Gaps 2011. [Citation: 18.12. 2011]. Available at: http://www.hmrc.gov.uk/stats/mtg-2011.pdf.

HM Customs and Excise (2012), Preliminary Estimate of the VAT Gap for 2011/2012. [Citation: 22.3.2013]. 2012. Available at: http://www.hmrc.gov.uk/statistics/tax-gaps/vat-gap-2012.pdf.

Christie, E., Holzner, M. (2006), "What Explains Tax Evasion? An Empirical Assessment Based on European Data." WIIW, Working Paper 40, [Citation: 18.8. 2012], Available at: http://www.wiiw. ac.at/pdf/wp40.pdf.

Novysedlak, V., Palkovičova, J. (2012), Estimate of the Value Added Tax Revenue Loss. Institute for Financial Policy, Ministry of Finance of the Slovak Republic, [Citation: 25.10. 2012]. Available at: http://www.finance.gov.sk/en/Components/CategoryDocuments/s_LoadDocument. aspx?categoryld=614\&documentld $=426$.

OECD (2002), Measuring the Non-Observed Economy: A Handbook. Paris: OECD Publications. ISBN 92-64-19745-1.

Reckon LLP (2009), "Study to Quantify and Analyze the VAT Gap in the EU-25 Member States", [Citation: 17.12. 2011], Available at: http://ec.europa.eu/taxation_customs/resources/documents/ taxation/tax_cooperation/combating_tax_fraud/reckon_report_sep2009.pdf.

Schneider, F., Buehn, A. (2007), "Shadow Economies and Corruption all over the World: Revised Estimates for 120 Countries”, Open-Access E-Journal, [Citation11.12. 2011]. Available at: http://www.economics-ejournal.org/economics/journalarticles/2007-9.

Schneider, F. (2012), "Size and Development of the Shadow Economy from 2003 to 2012: Some New Facts", Available at: http://www.econ.jku.at/members/Schneider/files/publications/2012/ ShadEcEurope31_March\%202012.pdf.

Transparency International (2000-2011), “Corruption Perception Index", Berlin: Transparency International Secretariat. [Citation11.11. 2012]. Available at: http://www.transparency.org/research/ cpi/overview.

US Internal revenue Service (1979), "Estimates of Income Unreported in Individual Income Tax Returns", Publication 1104, Government Printing Office, Washington.

Wooldridge, J. (2002), Econometric Analysis of Cross Section and Panel Data, Cambridge, MA: The MIT Press. 